Јелена Гинић ${ }^{1}$

Универзитет у Београду

Филолошки факултет
УДК 811.161.1'342.8

DOI 10.18485/zivjez.2016.36.1.9

Оригинални научни рад

\title{
СЕГМЕНТНИ И СУПРАСЕГМЕНТНИ ФОНЕТСКИ МАТЕРИЈАЛ У УЏБЕНИЦИМА РУСКОГ ЈЕЗИКА ЗА ОСНОВНУ ШКОЛУ
}

Циљ овог рада јесте доказивање хипотезе о неопходности ревизије наставног програма за основну школу за руски језик у погледу фонетског материјала. Указујући на кључне разлике фонетских система два језика, дефинисали смо кључне сегментне и супрасегментне особине артикулационе базе руског језика. Фреквенцијску анализу фонетског материјала уџбеника спровели смо шифрујући и експлицирајући фонетске (сегментне и супрасегментне) доминанте тематизоване у актуелним уџбеничким комплетима. Пратили смо њихову учесталост у читавом комплету и поредили је међусобно и с експлицираним особинама артикулационе базе руског језика. Потврђена је претпоставка неопходности ревизије наставног програма: двоструко мање су заступљене супрасегментне доминанте у уџбеницима (акценат речи, редукција вокала, интонација), кључне у руској артикулационој бази, док је кључна сегментна доминанта (парни тврди/меки гласови) заступљена у назнакама.

Кључне речи: фонетски материјал, артикулациона база, сегментне/супрасегментне јединице и средства, сегментна/супрасегментна доминанта, фреквенцијска анализа, уџбенички комплети Родничок и Орбита

\section{Увод}

Руски и српски језик припадају групи сродних, словенских језика и говорник српског језика уз основна знања фонетике, морфологије и творбе речи може да разуме или наслути значење више од 50\% речи руског језика (Николић 1979: 15). Без

\footnotetext{
1 jelenaginic@gmail.com
} 
обзира на генеалошку сродност, српски и руски језик имају крупне, типолошке, разлике у сегментним и супрасегментним фонетским јединицама и средствима (о сегментним и супрасегментним јединицам и средствима више у: Књазев и Пожарицка 2011: 18-19). О сегментним и супрасегментним разликама српског и руског језика писали смо у неколико наврата, уп. Гинић 2010: 152-161 и Гинић 2014: 23-28. Више о разликама само у сегментним јединицама и средствима и тематизованом фонетском материјалу у ова два уџбеника видети у Гинић, 2015: 46-62.

Још је 1963. године Петар Митропан писао о највећим тешкоћама усвајања руског фонетског система за говорнике српског језика: „За нашу децу нови фонетски елементи углавном су: 1) меки сугласници ${ }^{2}$; 2) изговор ненаглашених самогласника3 ; 3) улога $е$, ё, ю, я; 4) тврди гласови $л$ и ы ${ }^{4}$; 5) меки ч и щ; 6) тврд изговор жи и ши; 7) удвојени сугласници нн, жж, $c$; 8) акценат и, касније, 9) интонација..“ (Митропан 1963: 6) 6 .

2 Већ на првом месту Петар Митропан наводи меке сугласнике као новину и тешкоћу у усвајању. Њима није посвећена довољна пажња, како ћемо видети даље у раду, поготово парним тврдим и меким сугласницима на које Митропан и мисли (даље помиње поједине увек меке), иако је ова фонетска појава врло тешка за усвајање. Нарочито се тешко усвајају меки двоуснени и уснено-зубни, којима се пажња, готово и не посвећује (о овоме је писао у својој Фонетици руског језика и Александар Терзић (Терзић 2003: 62)).

3 На друго место Петар Митропан ставља редукцију вокала, која, како ћемо видети, заузима веома важно место у оквиру супрасегментних јединица.

4 Глас [ы], наравно, не може бити тврд, он је самогласник. У периоду када је Петар Митропан писао своју Методику наставе руског језика, у српској методичкој и фонетској литератури сретао се често (мада врло погрешан) назив датог гласа „тврдо ы“.

5 Експериментално акустичко истраживање Л. Е. Лузикове, рецимо, показало је да су интонациони системи мађарског и руског језика сличнији него системи српског и руског језика (в. Лузикова 2011) што истиче важност тематизације датог супрасегментног средства.

6 П. Митропан све време меша чињенице везане за „правопис“ с „фонетским“ чињеницама. (видети ставке 3 и 4 у цитату); на овај начин су се интерпретирале фонетске чињенице у времену у ком је он писао. Данас, ипак, на ове недоследности морамо указати. 
Многи руски фонетичари и лингвисти експлицирају конкретне карактеристике руске артикулационе базе7, међу последњима то чине Књазев и Пожарицка (в. Књазев и Пожарицка 2011: 189-190). Имајући у виду њихове претпоставке, као и претпоставке Ј. А. Бризгунове и И. А. Одинцове (в. Бризгунова 1977, 1969; Одинцова 2008) уобличили смо следећа наша запажања. Како би се исправно формирале фонетске навике и умења, морамо имати у виду следеће особености руске артикулационе базе у односу на српску:

1) постојање „палатализације“ као појаве у савременом руском језику; српски језик не познаје ову допунску артикулацију у синхронијском значењу ${ }^{8}$, односно, не познаје опозиције палатализован / непалатализован сугласнички глас. Правилан изговор палатализованих гласова кључан је фактор за правилан изговор наредног акцентованог или неакцентованог вокалског гласа;

2) постојање неједнородних вокалских акцентованих гласова, дифтонгоида и полифтонгоида у руском језику. Српски језик овакве гласове не познаје, стога говорник српског језика мора да усваја нове навике „отворености“, односно „затворености конкретних вокалских гласова“;

3) постојање специфичне ритмике речи. Артикулациона база српског језика није навикнута на ову специфичност;

4) постојање акценатског језгра, које обухвата акцентовани и први предакцентовани слог, а које артикулациона база српског језика не познаје;

7 Артикулациону базу посматрамо као „систем рада говорног апарата“ (Бризгунова 1977: 83) у оквиру кога се дефинишу карактеристике који дати „рад говорног апарата“ чине специфичним и компликованим за усвајање.

8 Под палатализацијом се подразумева да палатализован сугласнички глас, поред основне артикулације има и допунску, језичну артикулацију. Палатализација се огледа у покрету предњег и средњег дела језика према тврдом непцу. Будући да у руском језику има 15 палатализованих сугласничких гласова од 37 , можемо закључити да се језик врло често креће према тврдом непцу. Овај покрет није својствен артикулационој бази српског језика, односно морамо усвојити нову навику. 
5) постојање узлазно-силазног мелодијског кретања тона с наглим узлазним покретом тона и почетком пада у оквиру истог вокалског гласа. Овакво кретање тона, типично за артикулациону базу руског језкика, српски језик не познаје;

6) могућност брзог пребацивања (рус. „переключение“) с једног типа артикулације на други (меки сугласнички гласови могу да стоје поред тврдих гласова), или: „лакоћа прелаза с „режима” палатализације на „режим непалатализације”, односно лакоћа алтернирања „тврдих” и „меких” слогова9 у оквиру исте речи“ (Корниенко 1995: 52).

Додали бисмо још две особености, које аутори нису убројали у скуп устаљених говорних навика, па самим тим ни у одлике руске артикулационе базе, које дати репертоар одлика руске артикулационе базе у односу на српску допуњују:

1) постојање квантитативне и квалитативне редукције неакцентованих вокалских гласова. Артикулациона база српског језика не познаје редукције вокалских гласова;

2) постојање великог броја реалних и психолошких пауза у оквиру исказа. Српски језик има потпуно различите навике сегментације, ређе се праве паузе у српском језику, док се у руском паузе праве много чешће, и на оним местима у којима их у српском нема, о чему смо писали раније (в. Гинић 2014).

Циљ нашег рада је да кроз фреквенцијску анализу фонетског материјала у актуелним уџбеницима руског језика за основну школу у Србији покаже колика пажња се посвећује сегментном и супрасегментном материјалу, имајући у виду претпоставку да су за говорнике српског језика најважније управо наведене карактеристике (палатализовани /непалатализовани гласови, редукција вокала, неједнородност акцентованих вокала, акценатско језгро, специфично кретање мелодијског тона с наглим узлазним и силазним покретом у оквиру истог гласа, носиоца акцента). Коначно, радом ћемо указати на потребе ревизије наставног програма у погледу фонетског материјала, укључивања појединих, кључних, партија у наставни програм, а самим тим и у уџбенике.

9 Корниенко сматра да се „опозиција „тврдоћа” - „мекоћа” реализује на целом слогу“ (Корниенко 1995: 52). 


\section{Фреквенцијска анализа. \\ Фонетска (сегментна/супрасегментна) доминанта}

Према уџбеничком комплету Родничок шифровали смо сваки тематизовани детаљ фонетског материјала (сегментног и супрасегментног) који се презентује или увежбава у конкретној лекцији, назвавши га фонетском (сегментном или супрасегментном) доминантом (наш термин) ${ }^{10}$. Шифровање фонетских доминанти омогућило нам је фреквенцијску анализу (на нивоу целог уџбеничког комплета, не сваке лекције појединачно), која нам је показала које се фонетске јединице или средства у ком уџбеничком комплету најзаступљеније. Дата анализа пружила нам је материјал за обиље закључака разне врсте: зашто су одређене фонетске доминанте фреквентне, а друге не, да ли се фреквенција фонетских доминанти разликује између актуелних уџбеничких комплета, покушали смо да објаснимо зашто одређене, врло важне доминанте, потпуно изостају. Коначно, уочили смо и које то доминанте нису довољно или никако заступљене у школској настави фонетике и интонације у нашој средини.

\section{Шифре фонетских супрасегментних доминанти у комплету Родничок}

У оквиру анализе сваке лекције појединачно уџбеничког комплета Родничок, поред сваке појединачне сегментне или супрасегментне доминанте стоји шифра. Шифре за доминанте

10 Зашто смо се определили баш за термин доминанта? Чињеница је да се фонетски материјал врло ретко у уџбеницима презентује изоловано, већ се у оквиру одређених вежби, морфолошких категорија или читања стихова, наводи одређено фонетско правило и увежбава. Овакав материјал назива се још и „неспецијалним” (Пасов 1989: 168). Пошто одређена фонетска појава „доминира” у датом материјалу, ми смо је назвали „доминантом”. Наравно, потпуно смо занемарили онај „неспецијални” материјал у коме аутори уџбеника указују на чињеницу да треба водити рачуна о изговору и интонацији. 
смо разрадили према комплету Родничок, а користили смо их и за остале анализиране уџбенике и уџбеничке комплете, допуњујући листу уколико дате доминанте у комплету Родничок није било.

Шифровање (нумерацију) смо вршили на следећи начин:

1) Цифра 1 (на пирмер, 1.1) на првом месту означава припадност сегментним јединицама или средствима; цифра 2 (2.1) на првом месту значи припадност конкретне доминанте супрасегментном нивоу (јединицама или средствима);

2) Цифра 1 на другом месту (на пример, доминанта 1.1) значи да сегментна доминанта припада тврдим сугласничким гласовима; цифра 2 на другом месту (доминанта 1.2) означава да сегментна доминанта припада меким гласовима. Следи доминанта 1.3. која означава презентацију меких и тврдих парних сугласничких гласова, затим 1.4. - алтернације сугласничких гласова и 1.5. - звучни и безвучни гласови;

3) Доминанта 2.1. тиче се прозодијског средства „акцента речи“, доминанта 2.2. - интонације исказа.

Следе конкретне доминанте које се појављују у комплету Родничок. Конкретне доминанте смо шифровали према редоследу појављивања у уџбеницима.

\section{0. Сегментне доминанте}

1.1. Тврди сугласнички гласови:

1.1.1. Конкретни тврди сугласнички гласови:

1.1.1.1. Глас [р];

1.1.1.2. Глас [ш];

1.1.1.3. Глас [ж];

1.1.1.4. Глас [ц]:

1.1.1.4.1. Резултат читања слова ч (и у словним групама цы и ци);

1.1.1.4.2. Резултат читања словних група ться и тся [ц:];

1.1.1.5. Глас [в]:

\subsubsection{1. Резултат читања г у}

словној групи ого.

1.1.2. Тврди гласови пред гласом [e] у речима страног порекла. 
1.1.3. Дуги тврди сугласнички гласови;

1.2. Меки сугласнички гласови:

1.2.1. Конкретни меки сугласнички гласови;

1.2.1.1. Глас [л'];

1.2.1.2. Глас $\left[\mathrm{T}^{\prime}\right]$;

1.2.1.3 Глас [д'];

1.2.1.4. Глас [ч'];

1.2.1.5. Глас [ш'];

1.2.1.5.1. Резултат читања слова щ;

1.2.1.5.2. Резултат читања словне групе сч;

1.2.1.6. Глас [j]

1.2.1.6.1. Резултат читања словне групе с «деоним» знаком;

1.2.1.6.2. Резултат читања слова я, е, ё, юу неприкривеном слогу;

1.2.1.7. Глас [c']

1.2.2. Дуги меки сугласнички гласови

1.2.3. Мек глас чија је мекоћа обележена меким знаком

1.3. Меки и тврди парни сугласнички гласови

1.4. Алтернације сугласничких гласова

1.4.1. Алтернације с нулом гласа

1.4.1.1. Резултат читања словне групе вств;

1.4.1.2. Резултат читања словне групе здн;

1.4.1.3. Резултат читања словне групе йст;

1.4.1.4. Резултат читања словне групе стн;

1.4.1.5. Резултат читања словне групе $p \partial u ;$

1.4.1.6. Резултат читања словне групе $c m л$;

1.4.2. Алтернације звучних са безвучним

сугласничким гласовима и безвучних

са звучнима:

1.4.2.1. Алтернација [д] са [т] (на крају речи и пред безвучним гласом);

1.4.2.2. Алтернација [ж] са [ш] (на крају речи и пред безвучним гласом); 
1.4.2.3. Алтернација [3] са [c] (на крају речи и пред безвучним гласом);

1.4.2.4. Алтернација [б] са [п] (на крају речи и пред безвучним гласом);

1.4.2.5. Алтернација [в] са [ф] (на крају речи и пред безвучним гласом);

1.5. Звучни и безвучни сугласнички гласови.

\section{0. Супрасегментне доминанте}

2.1. Доминанте везане за прозодијско средство „акценат речи“:

2.1.1. Акцентовани вокалски гласови

2.1.1.1. Изговор акцентованог гласа [ы];

2.1.1.3. Изговор акцентованог гласа [э] ${ }^{11}$;

2.1.1.4. Изговор акцентованог гласа [y];

2.1.1.5. Изговор акцентованог гласа [о];

2.1.1.6. Изговор акцентованог гласа [и].

2.1.2. Неакцентовани (редуковани) вокалски гласови

2.1.2.1. Први степен редукције: читање слова и,ы, у

2.1.2.2. Први степен редукције: читање слова а,о после тврдих сугласничких гласова;

2.1.2.3. Први степен редукције: читање слова а, е, я после меких сугласничких гласова;

2.1.2.4. Други степен редукције: читање слова и, ы, у

2.1.2.5. Други степен редукције: читање слова а, о;

2.1.2.6. Други степен редукције: читање слова а, е, я.

2.2. Доминанте везане за прозодијско средство „интонација исказа“:

11 изостаје доминанта 2.1.1.2 (која би тематизовала акцентивани глас [а]. Наиме, ова доминанта се у уџбенику Родиничок не појављује, па је, с обзиром на систем шифровања, требало наредну доминанту шифровати последњом цифром 2. Овде је направљена омашка у шифровању, али је сав материјал доследно анализиран, а доминанта 2.1.1.2 која тематизује акцентовани глас [а] појављује се у комплету Орбита. 
2.2.1. Једносинтагматски искази

2.2.1.1. Интонација обавештајних исказа;

2.2.1.2. Интонација упитних исказа с упитном речју;

2.2.1.3. Интонација упитних исказа без упитне речи;

2.2.1.4. Интонација узвичних исказа;

2.2.2. Вишесинтагматски искази

2.2.2.1. Набрајање у унутрашњим фонетским синтагмама;

2.3. Акценатске целине 2.3.1. Фонетска реч.

\begin{tabular}{|c|c|c|}
\hline & Сегментне доминанте & Супрасегментне доминанте \\
\hline Родничок 1 & 1.2. (у 4 лекције); & $\begin{array}{l}\text { 2.1.1.1. (у } 4 \text { лекције); 2.1.2; } \\
\text { (у } 4 \text { лекције). }\end{array}$ \\
\hline Родничок 2 & $\begin{array}{l}\text { 1.2.1.1, 1.2.1.2, 1.2.1.3, 1.2.1.4. (у } 3 \\
\text { лекције); 1.1.1.1, 1.1.1.2, 1.2.1.5. } \\
\text { (у } 2 \text { лекције). }\end{array}$ & / \\
\hline Родничок 3 & $\begin{array}{l}\text { 1.1, 1.2,1.2.1.6.1 (у } 2 \text { лекције); } \\
\text { 1.1.1.2,1.1.1.3, 1.1.1.4.2, 1.1.1.5.1, } \\
\text { 1.2.1.4 1.2.1.5, 1.4.1.1, 1.4.1.2. (у } \\
1 \text { лекцији) }\end{array}$ & $\begin{array}{l}\text { 2.1.1. (у } 1 \text { лекцији); 2.1.2.2., } \\
\text { 2.1.2.5 }{ }^{12} ; 2.1 .2 .3,2.1 .2 .6 \text { (у } 1 \\
\text { лекцији). }{ }^{13}\end{array}$ \\
\hline Родничок 4 & $\begin{array}{l}\text { 1.3, 1.5, 1.1.1.2, 1.1.1.3, 1.1.1.4, } \\
\text { 1.2.1.6.1, 1.4.2. (у } 1 \text { лекцији). }\end{array}$ & $\begin{array}{l}\text { 2.1.1.1. (у } 2 \text { лекције), 2.1.2.2., } \\
\text { 2.1.2.5 } \\
\text { лекцији). } .^{15}\end{array}$ \\
\hline Родничок 5 & $\begin{array}{l}\text { 1.1.1.2, 1.2.1.6.1 (2 понављања); } \\
\text { 1.1.1.3,1.1.1.4, 1.1.4.2, 1.2.1.4, } \\
\text { 1.2.1.5.1,1.2.1.6.2, 1.4.1, 1.4.2.1, } \\
\text { 1.4.2.2. (1 понављање). }\end{array}$ & $\begin{array}{l}\text { 2.1.2.3 (3 понављања), 2.2.1.3 } \\
\text { (2 понављања), 2.1.2.2 и } \\
\text { 2.1.2.5. (два понављања), } \\
\text { 2.1.2.6 (два понављања) }\end{array}$ \\
\hline Родничок 6 & $\begin{array}{l}\text { 1.2.1.6.1 (3 понављања), 1.1.1.5.1, } \\
\text { 1.4.2.1, 1.4.2.2 (2 понаваљања), } \\
\text { 1.1.1.2, 1.1.1.3,1.1.1.4.1,1.2.1.4, } \\
\text { 1.2.1.6.2, 1.2.1.5.1, 1.4.1, 1.4.2, } \\
\text { 1.4.2.3 (1 понављање). }\end{array}$ & $\begin{array}{l}\text { 2.1.2.2, 2.1.2.5, (3 понављања), } \\
\text { 2.2.1.3 (два понављања) } \\
\text { 2.2.1.1, 2.2.1.4. }\end{array}$ \\
\hline Родничок 7 & $\begin{array}{l}\text { 1.3. (2 понављања);1.1.1.4.2, } \\
\text { 1.1.1.5.1, 1.4.1. (1 понављање). }\end{array}$ & $\begin{array}{l}\text { 2.2.1.3 (3 понављања); 2.1.2.2, } \\
\text { 2.1.2.5, (3 понављања); } \\
\text { 2.1.1, 2.2.1.1. (1 понављање). }\end{array}$ \\
\hline Родничок 8 & $\begin{array}{l}\text { 1.4.2, 1.2.1.6.1. (3 понављања); } \\
\text { 1.1.1.5.1, 1.1.2, 1.3, 1.4.1, (2 по- } \\
\text { нављања), 1.2.1, 1.2.1.4, 1.2.1.5.1, } \\
\text { 1.2.2, 1.4.1 (1 понављање). }\end{array}$ & $\begin{array}{l}\text { 2.1.2.2, 2.1.2.5 (2 понављања), } \\
\text { 2.2.2.1, 2.3.1 (1 понављање). }\end{array}$ \\
\hline
\end{tabular}

Табела 1. Фреквенција фонетских доминанти у комплету Родничок 
Уколико бисмо изоставили конкретизацију фонетских доминанти, свели их на две цифре и апстраховали читав комплет, добили бисмо следећи резултат:

\begin{tabular}{|l|c|c|}
\hline & Сегментне доминанте & Супрасегментне доминанте \\
\hline Родничок & $1.2 .(43)$ & $2.1 .(42) ;$ \\
& $1.1 .(27)$ & $2.1 .1 .(8)$ \\
& $1.4 .(16)$ & $2.1 .2 .(34)$ \\
& $1.3 .(4)$ & $2.2 .(11)$ \\
& $1.5 .(1)$ & $2.3 .(1)$ \\
\hline
\end{tabular}

Табела 2. Индекс понављања сегментних и прозодијских доминанти

Анализирајући резултате табеле 2, у којој смо све доминанте свели на две цифре (с тим што смо супрасегментне доминанте које се односе на вокалске гласове приказали и са три цифре - 2.1.1. се односи на акцентоване гласове, 2.1.2. на редуковане гласове, а обе доминанте заједно се садрже у 2.1), сабрали свако њихово појављивање у читавом комплету, можемо извести следеће закључке:

1) Сегментне доминанте имају већи „индекс“ појављивања у односу на супрасегментне, тај однос приближно је 91: 54, готово су двоструко учесталије;

2) Међу сегментним доминантама преовлађују доминанте које се односе на меке сугласничке гласове, доминанта 1.2. (конкретно гласови: [л'], [т'], [д'], [ч'], [ш:'], [j] и $\left.\left[\mathrm{c}^{\prime}\right]\right)$;

3) Следе тврди сугласнички гласови, доминанта 1.1. (конкретно гласови: [р], [ш], [ж], [ц], [в] и [л]);

4) За тврдим гласовима следе алтернације сугласничких гласова (1.4);

5) Тек 4 појављивања у читавом комплету имају парни тврди/меки сугласнички гласови (1.3);

12 Аутори изједначавају места 2.1.2.2. и 2.1.2.5.

13 Аутори изједначавају места 2.1.2.3. и 2.1.2.6.

14 Аутори не изједначавају места 2.1.2.2. и 2.1.2.5.

15 Аутори не изједначавају места 2.1.2.3. и 2.1.2.6. 
6) Звучни и безвучни помињу се само једанпут (1.5);

7) Најчешће супрасегментне доминанте тичу се акцентованих (2.1.1) и редукованих вокалских гласова (2.1.2). Од конкретних акцентованих гласова најчешће се презентује и увежбава глас [ы];

8) Следе редукције гласова (34 појављивања од 42) после тврдих сугласничких гласова („акање”, 22 понављања);

9) Редукције после меких гласова („икање”, 12 понављања ${ }^{16}$ );

10) Интонација исказа има упола мањи број понављања у односу на вокалске гласове, тиче се доминантно једносинтагматских исказа;

11) Само једном се презентује вишесинтагматски исказ, односно „интонација набрајања“. Коначно, једно појављивање има и „фонетска реч” у оквиру одељка „акценатска целина“.

\section{Шифре фонетских доминанти у комплету Орбита}

\section{0. СЕГМЕНТНЕ ДОМИНАНТЕ:}

1.1. Тврди сугласнички гласови

1.1.1. Конкретни тврди сугласнички гласови:

1.1.1.2. Глас [ш];

1.1.1.3. Глас [ж];

1.1.1.4. Глас [ц]:

1.1.1.4.1. Резултат читања слова $u$ (и у словним групама цы и ци);

1.1.1.4.2. Резултат читања словних група ться и тся [ц:];

1.1.1.4.3. Резултат читања словних група ти и $\partial u$

1.1.1.5. Глас [в]:

1.1.1.5.1. Резултат читања слова 2 у словној групи ого.

1.1.2. Тврди гласови пред гласом [e] у речима страног порекла.

16 „Икање“ представља доминанту која се теже усваја, тако да би, индекс појављивања морао да буде бар за двоструко већи у односу на „акање“. 
1.1.3. Дуги тврди сугласнички гласови;

1.2. Меки сугласнички гласови:

1.2.1. Конкретни меки сугласнички гласови;

1.2.1.4. Глас [ч'];

1.2.1.5. Глас [ш'];

1.2.1.5.1. Резултат читања слова щ;

1.2.1.5.2. Резултат читања словних група сч;

1.2.1.6. Глас [j]

1.2.1.6.1. Резултат читања словне групе с „деоним“ знаком;

1.2.1.6.2. Резултат читања слова $я, e$, ё, ю у неприкривеном слогу;

1.2.2. Дуги меки сугласнички гласови

1.3. Меки и тврди парни сугласнички гласови

1.4. Алтернације сугласничких гласова

1.4.1. Алтернације с нулом гласа

1.4.1.1. Резултат читања словне групе вств;

1.4.1.2. Резултат читања словне групе здн;

1.4.1.3. Резултат читања словне групе йст;

1.4.1.4. Резултат читања словне групе $c m н$;

1.4.1.5. Резултат читања словне групе $p \partial u ;$

1.4.2. Алтернације звучних са безвучним сугласничким гласовима и обрнуто:

1.4.2.1. Алтернација [д] са [т] (на крају речи и пред безвучним гласом);

1.4.2.2. Алтернација [ж] са [ш] (на крају речи и пред безвучним гласом);

1.4.2.3. Алтернација [3] са [c] (на крају речи и пред безвучним гласом);

1.4.2.4. Алтернација [б] са [п] (на крају речи и пред безвучним гласом);

1.4.2.5. Алтернација [в] са [ф] (на крају речи и пред безвучним гласом);

1.4.2.6. Алтернација [г] са [к] (на крају речи и пред безвучним гласом)

1.4.2.7. Алтернација [c] са [з] (пред звучним гласом) 
1.4.2.8. Алтернација [т] са [д] (пред звучним гласом)

1.4.2.9. Алтернација [к] са [г] (пред звучним гласом)

1.4.3. Алтернације по начину творбе

1.4.3.1. Алтернација [ч] са [ш] у речи что; као и чн (скучно)

1.4.3.2. Алтернација [т] са [ч'] у словној групи тч

1.5. Звучни и безвучни сугласнички гласови.

1.6. Специфичан начин читања слова у појединимречима: 1.6.1. [ш] уместо [щ] у речи помощник;

2.0. Супрасегментне доминанте:

2.1. Доминанте везане за супрасегментно фонетскосредство „акценат речи“:

2.1.1. Акцентовани вокалски гласови

2.1.1.1. Изговор акцентованог гласа [ы]; 2.1.1.1.1. Алтернација [и]॥[ы] на граници предлог:корен

2.1.1.2. Изговор акцентованог гласа [а];

2.1.1.3. Изговор акцентованог гласа [э];

2.1.1.3.1. [э] на апсолутном почетку речи (бележи се словом э)

2.1.1.5. Изговор акцентованог гласа [о];

2.1.1.6. Изговор акцентованог гласа [и].

2.1.2. Неакцентовани (редуковани) вокалски гласови

2.1.2.2. Први степен редукције:

читање слова $a, o$ после тврдих сугласничких гласова

2.1.2.3. Први степен редукције: читање слова $a, e, я$;

2.1.3. Место акцента у речи

2.1.3.1. Место акцента у хомографима

2.1.3.2. Место акцента у хомоформама

2.2. Доминанте везане за супрасегментно фонетско средство „интонација исказа“:

2.2.1. Интонација једносинтагматских исказа различитих комуникативних усмерења. 
Јелена Гинић

2.2.1.1. Интонација обавештајних исказа;

2.2.1.2. Интонација упитних исказа с упитном речју;

2.2.1.3. Интонација упитних исказа без упитне речи;

2.2.1.5. Интонација упитних исказа с везником $A$ на почетку;

2.2.2. Вишесинтагматски искази:

2.2.2.2. Синтагме, незавршене по смислу.

\section{Фреквенцијска анализа}

\begin{tabular}{|c|c|c|}
\hline & Сегментне доминанте & $\begin{array}{c}\text { Супрасегментне } \\
\text { доминанте }\end{array}$ \\
\hline Орбита 1 & $\begin{array}{l}1.3 \text { (3 понављања), } 1.2 .1 .4 \text { (2 } \\
\text { понављања), 1.2.1.6.1 (2 понављања), } \\
\text { 1.2.1.6.2 (2 понављања), 1.1, 1.1.1.2, } \\
\text { 1.1.1.3, 1.1.1.4.2, 1.1.1.5.1, , 1.2.1.5.1, } \\
\text { 1.2.1.5.2, , 1.4.1.1, 1.4.1.2, 1.4.1.3, 1.4.1.4, } \\
\text { 1.4.1.5, 1.4.2. }\end{array}$ & $\begin{array}{l}2.1 .1 \text { (2 понављања), } \\
2.1 .1 .1 \text { ( } 2 \text { понављања), } \\
2.1 .1 .6 \text { (2 понављања), } \\
2.1 .1 .2,2.1 .1 .5,2.1 .2 \\
2.1 .2 .2,2.2 .1 .2,2.2 .1 .3 .\end{array}$ \\
\hline Орбита 2 & $\begin{array}{l}\text { 1.1.1.4 (2 понављања), 1.2.1.6.1 (2 по- } \\
\text { нављања), 1.4.1.1 (2 понављања), } 1.4 .1 .2 \\
\text { (2 понављања), } 1.4 .1 .3 \text { (2 понављања), } \\
\text { 1.1.1.2, 1.1.1.1.3, 1.1.1.4.1, 1.1.1.4.2, } \\
\text { 1.1.1.5.1, 1.2.1.4, 1.2.1.5, 1.2.1.6.2, } \\
\text { 1.3, 1.4.1.4, 1.4.1.5, 1.4.2.1, 1.4.2.2, } \\
\text { 1.4.2.3,1.4.2.5, 1.4.2.6, 1.4.2.7,1.4.2.8, } 1.5 .\end{array}$ & $\begin{array}{l}2.1 .3 \text { (2 понављања), } \\
2.1 .1 .2,2.1 .1 .5,2.1 .2 .2, \\
2.2 .1 .5 .\end{array}$ \\
\hline Орбита 3 & $\begin{array}{l}\text { 1.1.1.4.2 (2 понављања), } 1.2 .1 .6 \text { (2 } \\
\text { понављања), 1.1.1.4.3,1.1.2, 1.2.1.5.2, } \\
\text { 1.4.2.1, 1.4.2.2, 1.4.2.3, 1.4.2.4, 1.4.2.6, } \\
\text { 1.4.3.1, 1.4.3.3, 1.6.1, }\end{array}$ & $\begin{array}{l}\text { 2.2.1.1 (2 понављања), } \\
2.2 .1 .3 \text { (2 понављања), } \\
2.1 .2 .2,2.2 .1 .2,2.2 .1 .5, \\
2.2 .2 .2 .\end{array}$ \\
\hline Орбита 4 & $\begin{array}{l}1.3 \text { (2 понављања),1.1.1.2, 1.1.1.3, 1.1.1.4, } \\
\text { 1.1.1.4.2, 1.1.3, 1.2.1.4, 1.2.1.5.1, 1.2.1.5.2, } \\
\text { 1.2.1.6.1, 1.2.1.6.2, 1.2.2, 1.4.1.2, 1.4.1.4, } \\
\text { 1.4.2.1, } 1.4 .2 .2,1.4 .2 .3,1.4 .2 .4,1.4 .2 .5 \\
1.4 .2 .6,1.4 .2 .7,1.4 .2 .8,1.4 .2 .9\end{array}$ & $\begin{array}{l}\text { 2.1.1.1, 2.1.1.1.1, } \\
2.1 .1 .3 .1,2.1 .3 .1,2.1 .3 .2 .\end{array}$ \\
\hline
\end{tabular}

Табела 3. Фреквенција фонетских доминанти у комплету Орбита

Уколико бисмо изоставили конкретизацију фонетских доминанти, свели их на две цифре и апстраховали читав комплет, добили бисмо следећи резултат: 
СЕГМЕНТНИ И СУПРАСЕГМЕНТНИ ФОНЕТСКИ МАТЕРИЈАЛ...

\begin{tabular}{|c|c|c|}
\hline & Сегментне доминанте & Супрасегментне доминанте \\
\hline \multirow{2}{*}{ орбита } & $1.2 .(22)$ & $2.1 .(20) ;$ \\
& $1.1 .(20)$ & $2.1 .1 .(12)$ \\
& $1.3 .(6)$ & $2.1 .2 .(4)$ \\
& $1.4 .(4)$ & $2.1 .3 .(4)$ \\
& $1.5 .(1)$ & $2.2 .(10)$ \\
\hline
\end{tabular}

Табела 4. Индекс понављања сегментних и прозодијских доминанти

После анализе табеле 4 у којој смо све доминанте свели на две цифре (с тим што смо супрасегментне доминанте које се односе на вокалске гласове приказали и са три цифре - 2.1.1. се односи на акцентоване гласове, 2.1.2. на редуковане гласове, а 2.1.3. на место акцента у речима истог словног састава; све три доминанте заједно се садрже у 2.1.), сабрали свако њихово појављивање у читавом комплету, можемо извести следеће закључке:

1) Сегментне доминанте имају готово двоструко већи „индекс“ појављивања у односу на супрасегментне, тај однос приближно је 56:30

2) Највећи број појављивања имају меки сугласнички гласови, доминанта 1.2. (најчешћи је глас [j], следе [ч'] и [ш']; укупно 22 понављања ${ }^{18}$;

3) Тврди гласови имају индекс од 20 понављања (најчешћи су [ж], [ш] и [ц]) ${ }^{19}$;

4) Тек шест понављања имају парни тврди и меки сугласнички гласови $(1.3)^{20}$;

5) Алтернације сугласничких гласова се појављују 4 пута ${ }^{21}$;

17 Исто као у комплету Родничок.

18 Слично као у комплету Родничок, с тим што је тежиште овде на гласовима који су увек меки.

19 Слично као у комплету Родничок, с тим што је и овде тежиште на гласовима који су увек тврди.

20 Нешто више него у претходном комплету (4); ово је знатно више, будући да дати комплет обухвата 4 године учења, док претходни обухвата 8 година учења.

21 У табели 3 их је више, јер се увек појављује неколико конкретних алтернација гласова у низу, па смо побројали сваку појединачно. Међутим, у самим уџбеничким комплетима се понављају свега 4 пута, сваке године по једанпут. 
6) Звучни и безвучни помињу само једанпут у читавом комплету (1.5);

7) Најчешће прозодијске доминанте тичу се акцентованих вокалских гласова (2.1.1) са дванаест понављања и редукованих вокалских гласова (2.1.2) са само 4 понављања; најчешћи акцентовани глас је глас [ы], најчешће презентован у контрасту с гласом [и] $]^{22}$;

8) Тематика посвећена месту акцента у речи у ужем смислу појављује се четири пута у читавој серији уџбеника;

9) Интонација исказа има упола мањи број понављања у односу на вокалске гласове, тиче се доминантно једносинтагматских исказа ${ }^{23}$;

10) Само једно појављивање има вишесинтагматски исказ, представљен интонацијом унутрашње синтагме двосинтагматског исказа.

\section{Закључак}

Централна фонетска сегментна доминанта би, према фонетским особеностима које експлицирају руски фонетичари у вези с артикулационом базом руског језика, као и фонетске тешкоће и разлике између два језика које наводимо и ми на почетним странама овог рада, требало да буде усвајање палатализованих сугласника, нарочито меких двоуснених и уснено-зубних. Њима се, притом, не придаје довољна пажња, односно, нити на један палатализовани уснени/уснено-зубни се не указује посебно у нашим изворима. У комплету Орбита при тематизацији конкретних меких гласова ниједан парни меки није заступљен, док су у комплету Родничок тематизовани гласови [т'], [д'] [c'] и [л']. У већој мери у оба комплета заступљени

22 комплет Родничок већу пажњу поклања кључној доминанти по којој се два фонетска система разликују - редукцији вокала (34:8 у корист редукованих гласова у односу на акцентоване, док је овај однос у комплету Орбита 4:12).

23 исто као у комплету Родничок. 
су увек меки руски [ч'], [ж:'] и [ш:'] и увек тврди [ж], [ш] и [ц], који се по квалитету разликују од српских. По нашем искуству, далеко је једноставније усвојити изговор увек меких и увек тврдих, њих разликују нијансе у квалитету, него палатализованих парних сугласника (којих у српском фонетском систему нема). Стога би дата карактеристика артикулационе базе требало да доминира програмом наставе сегментне фонетике свих година учења. Вежбе за усавршавање брзог „преоријентисања" артикулационе базе с тврдог на мек сугласник и обрнуто, такође би требало да буду заступљене у више наврата у току године.

С друге стране, супрасегментне карактеристике слабо су заступљене (двоструко мање у односу на сегментне), док су двоструко учесталије у карактеристикама саме артикулационе базе руског језика, што довољно говори о њиховом значају. Изненађује чињеница да се чешће тематизује „акање” (редукција вокала после тврдих сугласника) него „икање” (редукција после меких сугласника), које се много теже усваја. Неопходно је указивати и на квалитет акцентованих гласова (поново се највише пажње удељује вокалу [ы] ког нема у српском фонетском систему), док уопште нема указивања на различит квалитет акцентованих вокалских гласова у зависности од тога да ли се налазе после меких сугласника, што у огромној мери утиче на сам квалитет вокала, чинећи их дифтонгоидима и/или полифтонгоидима у руском језику. Веома важне партије у вези са супрасегментним јединицама/средствима изостају: сегментација исказа, интонација у вишесинтагматским исказима. Интонација је заступљена готово незнатно, везана је само за једносинтагматске исказе. Притом доминантна супрасегментна особина руске артикулационе базе (нагли узлазни и нагли силазни покрет тона у оквиру истог вокала, тематизована у упитним исказима без упитне речи) понавља се свега три пута у комплету Орбита (једанут у петом и два пута у седмом разреду), док се у комплету Родничок понавља 7 пута (два пута у петом и шестом разреду и три пута у седмом). Наглашавамо да је ово кључна доминанта, најфреквентнија у говору пред пау- 
зама у сегментацији вишесинтагматских исказа (незаступљена у овој улози у уџбеницима уопше). Због велике учесталости дату доминанту би требало заступити у готово свакој лекцији уџбеника, уткавши је, вежбама, у основни текст лекције.

Нагласили бисмо и чињеницу да су оба уџбеничка комплета врло квалитетна у погледу одабира текстова, граматичког материјала и материјала за вежбу и да оба комплета апсолутно задовољавају програмске захтеве у погледу фонетског материјала који тематизују, а у појединим сегментима га и превазилазе. Дати рад представља покушај указивања на неопходност ревизије фонетског материјала, кључних сегментних и супрасегментних доминанти, које се пре свега односи на програме. Уколико програм пропише њихову тематизацију и укаже на оно што је кључно (односно централно) и периферно, аутори неће имати недоумице у погледу квантитета, квалитета, па ни учесталости заступљености фонетског материјала.

\section{ИЗВОРИ}

Поповић, Љ., Гинић, J. (2003). Родничок 1. Руски језик за први разред основне школе. Београд: Завод за уџбенике и наставна средства. Поповић, Љ., Гинић, J. (2003). Родничок 1. Радна свеска. Београд: Завод за уџбенике и наставна средства.

Поповић, Љ., Гинић, J. (2003). Родничок 1. Приручник за наставнике. Београд: Завод за уџбенике и наставна средства.

Поповић, Љ., Гинић, J. (2004). Родничок 2. Руски језик за други разред основне школе. Београд: Завод за уџбенике и наставна средства.

Поповић, Љ., Гинић, J. (2004). Родничок 2. Радна свеска. Београд: Завод за уџбенике и наставна средства.

Поповић, Љ., Гинић, J. (2004). Родничок 2. Приручник за наставнике. Београд: Завод за уџбенике и наставна средства.

Поповић, Љ., Гинић, J. (2005). Родничок З. Руски језик за трећи разред основне школе. Београд: Завод за уџбенике и наставна средства.

Поповић, Љ., Гинић, J. (2005). Родничок 3. Радна свеска. Београд: Завод за уџбенике и наставна средства.

Поповић, Љ., Гинић, J. (2005). Родничок 3. Приручник за наставнике. Београд: Завод за уџбенике и наставна средства. 
Гинић, Ј., Тешић, А. (2006). Родничок 4. Руски језик за четврти разред основне школе. Београд: Завод за уџбенике и наставна средства.

Гинић, Ј., Тешић, А. (2006). Родничок 4. Радна свеска. Београд: Завод за уџбенике и наставна средства.

Гинић, J., Тешић, А. (2006). Родничок 4. Приручник за наставнике. Београд: Завод за уџбенике и наставна средства.

Поповић, Љ., Гинић, J. (2007). Родничок 5. Руски језик за пети разред основне школе. Београд: Завод за уџбенике.

Поповић, Љ., Гинић, J. (2007). Родничок 5. Радна свеска. Београд: Завод за уџбенике.

Поповић, Љ, Гинић, J. (2007). Родничок 5. Приручник за наставнике. Београд: Завод за уџбенике.

Поповић, Љ., Гинић, J. (2008). Родничок 6. Руски језик за шести разред основне школе. Београд: Завод за уџбенике.

Поповић, Љ., Гинић, J. (2008). Родничок 6. Радна свеска. Београд: Завод за уџбенике.

Поповић, Љ., Гинић, J. (2008). Родничок 6. Приручник за наставнике. Београд: Завод за уџбенике.

Поповић, Љ., Гинић, Ј. (2009). Родничок 7. Руски језик за седми разред основне школе. Београд: Завод за уџбенике.

Поповић, Љ., Гинић, J. (2009). Родничок 7. Радна свеска. Београд: Завод за уџбенике.

Поповић, Љ., Гинић, J. (2009). Родничок 7. Приручник за наставнике. Београд: Завод за уџбенике.

Поповић, Љ., Гинић, J. (2010). Родничок 8. Руски језик за осми разред основне школе. Београд: Завод за уџбенике.

Поповић, Љ., Гинић, J. (2010). Родничок 8. Радна свеска. Београд: Завод за уџбенике.

Поповић, Љ., Гинић, J. (2010). Родничок 8. Приручник за наставнике. Београд: Завод за уџбенике.

Пипер, П., Петковић М., Мирковић С. (2007). Орбита 1. Руски језик за пети разред основне школе. Београд: Завод за уџбенике.

Пипер, П., Петковић М., Мирковић С. (2007). Орбита 1. Радна свеска за пети разред основне школе. Београд: Завод за уџбенике.

Пипер, П., Петковић М., Мирковић С. (2007). Орбита 1. Приручник за наставникезапети разред основне школе.Београд: Заводза уџбенике.

Пипер, П., Петковић М., Мирковић С. (2008). Орбита 2. Руски језик за шести разред основне школе. Београд: Завод за уџбенике.

Пипер, П., Петковић М., Мирковић С. (2008). Орбита 2. Радна свеска за шести разред основне школе. Београд: Завод за уџбенике. 
Пипер, П., Петковић М., Мирковић С. (2008). Орбита 2. Приручник за наставнике за шести разред основне школе. Београд: Завод за уџбенике.

Пипер, П., Петковић М., Мирковић С. (2009). Орбита 3. Руски језик за седми разред основне школе. Београд: Завод за уџбенике.

Пипер, П., Петковић М., Мирковић С. (2009). Орбита 3. Радна свеска за седми разред основне школе. Београд: Завод за уџбенике.

Пипер, П., Петковић М., Мирковић С. (2009). Орбита 3. Приручник за наставнике за седми разред основне школе. Београд: Завод за уџбенике.

Пипер, П., Петковић М., Мирковић С. (2010). Орбита 1. Руски језик за осми разред основне школе. Београд: Завод за уџбенике.

Пипер, П., Петковић М., Мирковић С. (2010). Орбита 4. Радна свеска за осми разред основне школе. Београд: Завод за уџбенике.

Пипер, П., Петковић М., Мирковић С. (2010). Орбита 4. Приручник за наставнике за осми разред основне школе. Београд: Завод за уџбенике.

\section{ЛИТЕРАТУРА}

Бризгунова 1969: Брызгунова, Е. А. (1969). Звуки и интонация русской речи. Москва: Прогресс.

Бризгунова 1977: Брызгунова, Е. А. (1977). Звуки и интонация русской речи. Москва: Русский язык.

Гинић 2010: Гинич, Е. (2010). Учебная просодия русского языка в свете просодии сербского языка, Русский язык как инославянский, II, 152-161.

Гинић 2014: Гинич, Е. (2014). Особенности синтагматического членения русского и сербского языков и их связь с артикуляционной базой, Русский язык за рубежом, 4, 23-28.

Гинић 2015: Гинич, Е. (2015). Сегментный фонетический материал в учебниках русского языка для восьмилетних школ Сербии, $\mathrm{Ha}$ учный диалог, 3 (39), 46-62.

Књазев и Пожарицка 2011: Князев С. В, Пожарицкая, С. К. (2011). Сoвременный русский литературный язык. Фонетика, графика, орфография, орфоэпия. Москва: Академический Проект, Гаудеамус.

Корниенко 1995: Корниенко, Е. Р (1995). Вводно-фонетический курс в системе обучения иностранных учащихся русскому языку, Русский язык за рубежом, 2-3, 52-58. 
Лузикова 2011: Лузикова, Л. Э. (2011). Обучение иностранных учащихся русской интонации как средству реализации речевых интенций (пороговый уровень). Автореферат диссертации на соискание ученой степени кандидата педагогических наук. Москва.

Митропан 1963: Митропан, П. (1963). Методика наставе руског језика. Београд: Завод за издавање уџбеника СР Србије.

Николић 1979: Николић, В. (1979). Проблеми у настави руске лексике. Београд: Филолошки факултет.

Одинцова 2008: Одинцова, И. В. (2008). Звуки. Ритмика. Интонация: учебное пособие. Москва: Флинта, Наука.

Пасов 1989: Пассов, Е. И. (1989). Основы коммуникативной методики обучения иноязычному общению. Москва: Русский язык.

Терзић 2003: Терзић, А. (2003). Фонетика руског језика. Београд: Славистичко друштво Србије.

\title{
Елена Гинич
}

\section{СЕГМЕНТНЫЙ И СУПЕРСЕГМЕНТНЫЙ ФОНЕТИЧЕСКИЙ МАТЕРИАЛ В УЧЕБНИКАХ РУССКОГО ЯЗЫКА ДЛЯ ВОСЬМИЛЕТНИХ ШКОЛ СЕРБИИ}

\author{
Резюме
}

Во введении статьи наше внимание уделяется самому важному типологическому различию в сегментном и суперсегментном планах - оппозиции палатализованный/непалатализованный звук в русском языке (отсутствует в сербском языке), различию в самом частотном движении мелодического тона в русском языке по отношению к сербскому, редукции гласных, однородности/неоднородности гласных, синтагматическому членению. В русской артикуляционной базе важное место уделяется суперсегментным единицам и средствам. Они являются в два раза более частотными, чем сегментные единицы и средства. В статье мы представили результаты частотного анализа сегментного и суперсегментного материала в двух комплектах учебников русского языка: Родничок и Орбита. Сегментный и суперсегментный материал, выделенный из приведенных ком- 
плектов, мы назвали сегментными/суперсегментными доминантами. Иногда данный материал связан с грамматическим или лексическим, но для нас доминирующим является именно фонетический, поэтому наш термин - фонетическая (сегментная/суперсегментная) доминанта. Все доминанты мы зашифровали и записали каждое появление каждой из доминант в комплекте, чтобы получить материал для частотного анализа. Результаты мы представили в четырех таблицах. Обобщив результаты, мы пришли к выводу, что самой важной доминанте (палатализованный/непалатализованный звук) уделяется эпизодическое место в комплектах, а самым трудным для сербоговорящих звукам, губным и губно-зубным палатализованным отдельное место не уделено. В учебниках должны иметься упражнения по «переключению» слогов с твердым и мягким звуком в фонетическом слове, чему также особого внимания не уделяется. То же самое происходит с суперсегментыми доминантами: самой трудной (синтагматическому членению и резкому повышению/понижению мелодического тона, редукции гласных, особенно «иканью») очень мало места уделено. Слишком важное место уделено «всегда твердым» звукам русского языка и «всегда мягким» звукам. Все приведенные выводы приводят нас к более обобщенному выводу: нужности ревизии школьных программ в плане фонетического материала.

Ключевые слова: фонетический материал, артикуляционная база, сегментные/суперсегментные единицы и средства, сегментная/суперсегментная доминанта, частотный анализ, комплекты учебников Родничок и Орбита 